\title{
Supporting new arrival students' engagement with picture books: analysis of teacher talk using the appraisal theory
}

\author{
Celine PY Chu
}

\author{
Correspondence: \\ celine.chu@deakin.edu.au \\ Deakin University, Victoria, Australia
}

\begin{abstract}
For a considerable number of migrant and refugee children, their first experience of reading in a second language, and for some even their first encounter with printed materials, is in a new arrivals classroom. This paper looks at teacher talk with new arrival students as they were introduced to reading practices in a classroom. I attempt to use the Appraisal theory to investigate one teacher's talk, particularly on how she engages the students in reading and talking about children's picture books. Data for this study were obtained from a new arrivals classroom consisting of Year 6 and 7 students. Using a functional analysis provided by the Engagement system of the Appraisal theory, this paper aims to uncover some of the ways in which the teacher makes use of the verbal and visual resources in children's picture books to promote engagement with the texts. It is found that teacher talk plays a crucial role in supporting new arrival students' participation in practices associated with reading and talking about picture book texts. The analysis provides insights into how a teacher supports students with varying backgrounds of literacy experiences to engage with children's picture books.
\end{abstract}

Keywords: Classroom discourse analysis; Teaching reading; New arrival students; Appraisal theory

\section{Background}

Over the years individuals from communities around the world have entered Australia as migrants and refugees for different reasons. Some groups have been assisted to Australia from refugee camps, for example those from Sub-Sahara Africa and Afghanistan. One outcome of developments such as this is that the previous education experience of new arrival children may have been severely interrupted or in some cases, there may have been no previous education experience. This is commonly a result of the 'refugee experience' where there may not have been adequate and on-going access to school due to war and displacement, the lack of resources for the children to attend schools, or the children were simply not well enough to attend schools due to sickness caused by the harsh conditions in refugee camps (DEECD Department of Education and Early Childhood Development 2008: 8-9). Due to the vulnerability of new arrival students as a result of these prior experiences, more care and attention are needed to support them when they attend schools in Australia. For the majority of

(c) 2014 Chu; licensee Springer. This is an Open Access article distributed under the terms of the Creative Commons Attribution License (http://creativecommons.org/licenses/by/4.0), which permits unrestricted use, distribution, and reproduction in any medium, provided the original work is properly credited. 
new arrivals, being at a school also means they are learning to read and write for the first time.

Martin and Rose (2005) argue that school success depends largely on the student's ability to read independently with understanding. Rose (2007) presents a model of reading development explicating the two-way system underlying school reading practices (Figure 1).

At the same time that proposed pedagogic aims are executed to prepare students in achieving reading development at different levels of schooling, it is also evaluating the students by way of assessing whether they are able to perform the type of reading skills anticipated in the preceding stages. It is advocated in this model and elsewhere that young children should ideally begin to engage in the process of reading at home with their parents and caregivers before starting school (Martin and Rose 2005; Rose 2004, 2007). This model of reading development brings to light potential challenges for new arrival students learning to read in the classroom. For a considerable number of new arrival students such as in this study, the new arrivals classroom is where they will experience reading texts in the English language for the first time. In some cases it may even be their first encounter with printed materials. Therefore, the majority of students may not have possessed the reading skills that are required of students at their level of study, which is supposedly the ability to read independently as indicated in Figure 1. In fact, using the reading sequence model as a measure, for many new arrival students their reading level may well be equivalent to that indicated in the first stage or 'before school - learning to engage with reading'. Therefore, developing reading skills in such a context is complex as reading instruction has to be targeted at providing students with opportunities to simultaneously learn to engage with reading, to learn to read independently, as well as to learn from reading. Familiarity with these skills is important for new arrival students so that they do not continue to be disadvantaged even in classrooms supposedly targeted for their learning.

Although much has been written about first and second language learning in relation to reading development, yet not as much has been said for the teaching of reading in a

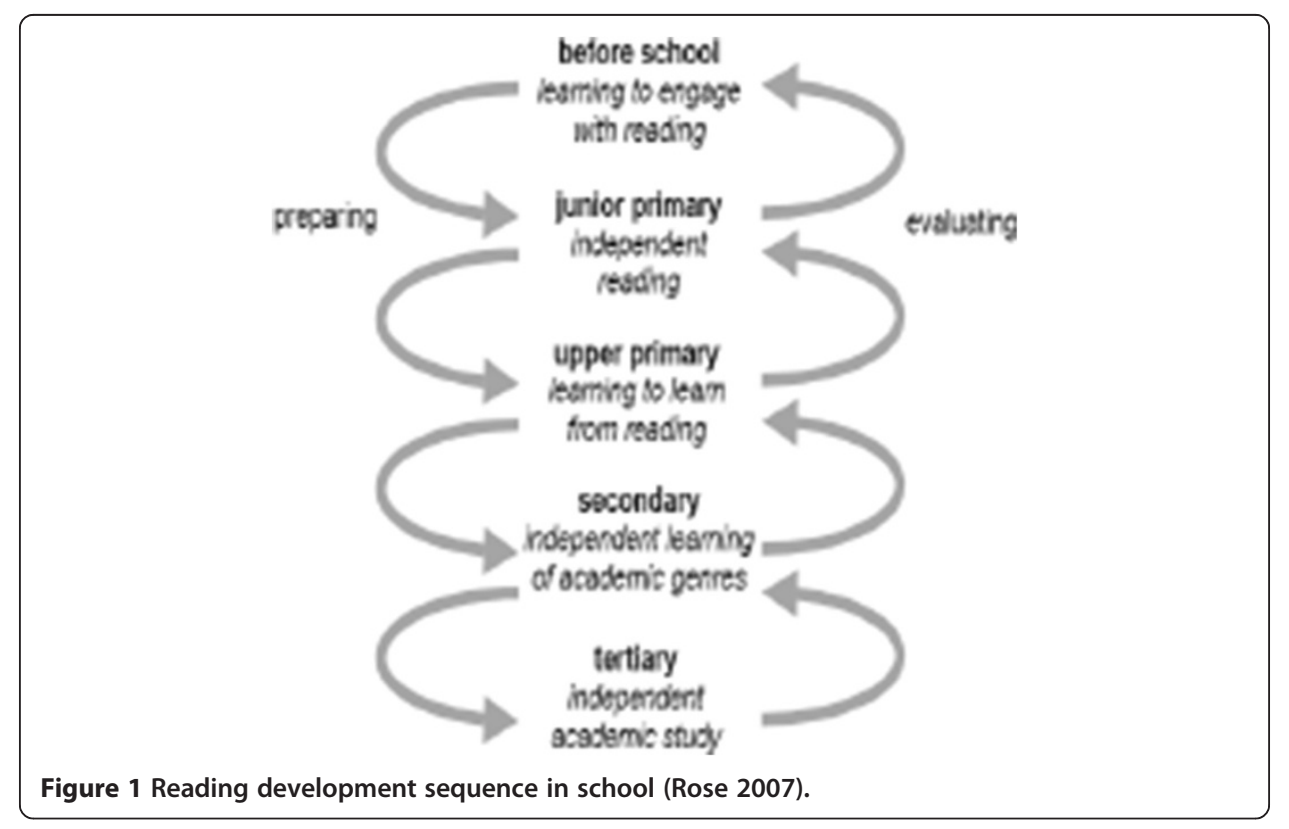


new arrivals classroom. Studies on reading development have primarily been concerned with whole language or top down (e.g. Goodman 1967; Smith 1971, 1983, 1994) and phonics or bottom up models (e.g. Gough 1972). Yet the phenomenon surrounding new arrival students deserves close attention beyond the identification of suitable reading models, to a need for an informed understanding of how teachers are working with students in classrooms. Some examples of studies as such have been previously undertaken on teacher talk in Science classrooms (Thwaite 2014; Thorne and Gericke 2014) and in other subject-specific classrooms, but little has been said on teacher talk with new arrival students in a book reading context. This paper attempts to make a contribution to this focus.

This paper presents an investigation of teacher talk as one teacher reads and talks about children's picture books with new arrival students. A systemic functional analysis drawing on the Engagement system of the Appraisal theory will be used in this study in the attempt to uncover from teacher talk, how the teacher makes use of the visual and verbal resources in picture books to engage students in reading practices. This study aims also to verify the efficacy of the Engagement system towards the analysis of teacher talk as this analytical tool has not been previously employed for such a purpose.

\section{Systemic functional linguistics}

Systemic functional linguistics views language as inseparable from its context of use. It is characterised as functional, semantic, semiotic and contextual (Halliday 1978). Language is functional because it is used to fulfil particular purposes; semantic as it is used to make meanings; semiotic because it provides sets of options for making meaning; and contextual for the reason that language use is influenced by social context. Therefore, systemic functional theory emphasises the inter-relations between language and the social system.

Likewise, the construction of spoken and written texts takes into account its social and cultural context (Martin and Rose 2008). According to the systemic functional theory, three social functions are established within any context of language use, known as field, tenor and mode. Field refers to the topic or focus of an activity; Tenor refers to the social role relationships played by interactants; and Mode describes the role that language plays in an interaction. Further, Halliday and Matthiessen (2004) suggest that language is used to serve any or all of three metafunctions that are the ideational meaning - to construe human experience, interpersonal meaning - to establish relationships with people around us, and textual meaning - to organise these construals and relationships with people into a cohesive text. Based on these theoretical understandings, texts differ from one to another as a result of variations in their metafunctions. This understanding also means that the systemic functional theory can be applied towards unpacking strands of meanings in spoken and written texts. For example, researchers have applied systemic functional analysis in a range of contexts such as parent-child or teacher-student interactions (see Hasan 1991; Christie 2002; Thwaite and McKay 2013), news reporting (see White 2006; Thomson et al. 2010), and multimodal texts (O'Halloran 1999; Unsworth and Cleirigh 2009). However, there has not been many studies that have examined teacher talk using the Appraisal theory. In this paper, I attempt a systemic functional analysis using the Appraisal theory to demonstrate how teacher talk 
encodes specific meanings and how these may impact on new arrival students' engagement with children's picture books.

\section{The appraisal theory}

The Appraisal theory is concerned with the interpersonal meaning in language use, for example how speakers/writers negotiate feelings with one another? or how certain attitudes are expressed in a speech/written text?. The strength of the Appraisal system is in its account for the nature of the complementarity between the 'inter' and 'personal' foci in spoken dialogue. Martin (2000a) explains that 'personal' meanings negotiated between speakers are not restricted only to expressions of mental states, but involves also the conveyance of attitudes as they adopt stances towards the material they present and those with whom they communicate with. What this means is that attitudes or feelings are conveyed alongside expressions of content in spoken interactions. Three broad areas of language use are considered within the system of Appraisal: Attitude, Engagement, and Graduation (Figure 2).

According to the Engagement system, utterances are either 'monoglossic' or 'heteroglossic'. An utterance is 'monoglossic' when it makes no reference to other voices, and 'heteroglossic' when other voices other than the speaker can be detected. Graduation is concerned with the grading of attitude by reference to the application of two senses. The first is that of Force, which refers to the 'degree of intensity' (Hood 2010: 85) or as Martin (2000b: 148) defines 'turning up the volume'. The second is concerned with adjustments by way of sharpening or softening that can be applied to the categorical meaning. The emphasis within the system of Attitude is on the emotions of interlocutors. A range of emotional reactions are accounted for through its sub-categories of Affect, Judgement, and Appreciation. The region of Affect concerns the 'resources for expressing feelings', whilst both Judgement and Appreciation are to do with the resources for 'judging character' and for 'valuing the worth of things' respectively (Martin and Rose 2003: 24).

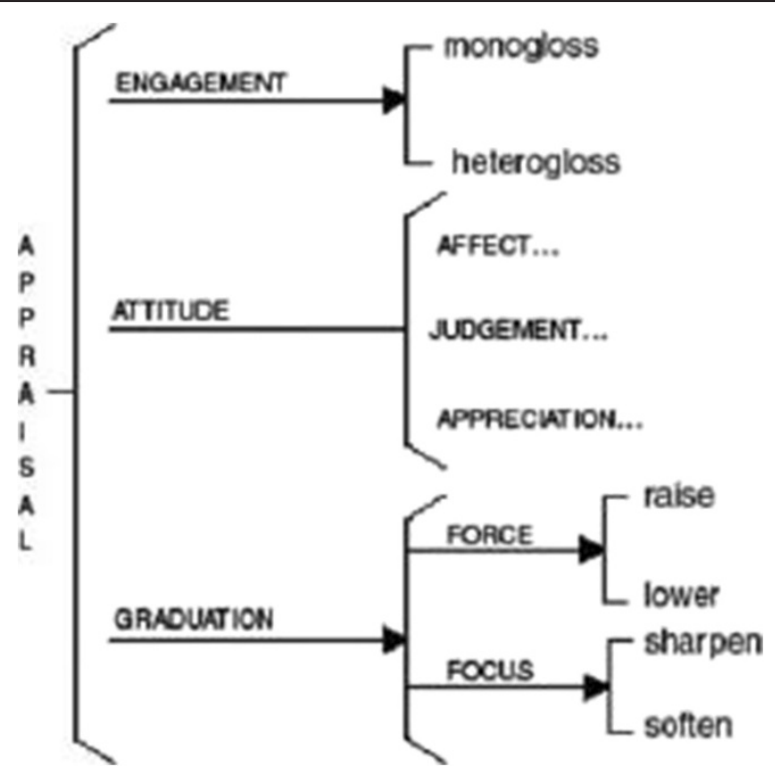

Figure 2 Three domains within the Appraisal system (Martin and White 2005). 
The Attitude system has often been applied to study interpersonal meanings in written texts. In Martin's (2001) analysis of the 'Mourning' editorial from a Hong Kong lifestyle magazine, for example, it is used to identify the Appraisal resources that conveyed feelings related to the events of 9/11. The analysis brings to light how the text unfolded with a universal communality to invoke readers' humanity or sorrow for another's loss and then moved on to more specific alignment that played on readers' moral and political response to American rhetoric.

Similarly, Hood and Martin (2007) draw on the Attitude system to argue that academic writers utilised inscribed attitude in the construction of arguments within their research. The study points out that academic writers often made use of valuation in the form of positive Appreciation, for example words such as significant are used to align readers to the value of a topic that is worthy of research. Further, Hood (2010) applies the Graduation system on research article introductions. Her analysis shows that authors used language in ways that functioned to grade or evaluate research undertaken by others. Analyses on written texts such as these demonstrate the strength of the Appraisal theory for unpacking the intentions of the writers as well as their stances in relation to the issues or materials. This also suggests the potential in the Appraisal theory for examining teacher talk.

To date there has been little attention on the application of the Appraisal theory to teacher talk around picture books. The analysis of teacher talk in this paper will draw on the Engagement system to identify, firstly the intentions of the teacher as she engages the students in discourse and secondly, her stance in relation to the visual and verbal resources in picture books. Martin (2014) proposes that the Engagement system provides the means for sourcing attitudes and managing heteroglossia. This means that the system accounts for the analysis of spoken interaction, in that it acknowledges the presence of more than one interactant. Further, resources in the system makes way for consideration of issues such as the ways in which the speaker/writer adopts a stance in relation to the value positions presented, of whether the speaker/writer aligns or disaligns listeners/ readers to their stances, and the ways in which the authorial voice positions itself in relation to other voices in a communicative event. This is of particular interest to this paper as the aim of the analysis is to uncover some of the ways that the teacher talks about the visual and verbal components in picture books, and how in doing so she engages the students in reading and talking about the texts. This analysis would provide insights into how the teacher supports new arrival students' engagement with picture books.

\section{Analysis of teacher talk using the engagement system}

The analysis here concentrates on the role of teacher talk as she engages the new arrival students in talk around children's picture books. Teacher talk is focused on as it interacts with the students, and at the same time it draws on the visual and verbal resources that construct the picture book texts. As a way into the discussion, I will present the options in the Engagement system and will draw on examples from the classroom talk data collected for this study to demonstrate the different categories of Engagement meanings.

The Engagement system categorises any utterances into two types: monoglossic or heteroglossic. Monoglossic utterances are those which 'make no reference to other voices and viewpoints', whereas heteroglossic assertions 'invoke or allow for dialogistic 
alternatives' (Martin and White 2005: 99-100). The Engagement system is presented in Figure 3.

The Engagement system provides the means for characterising speaker or writer voice as it 'positions itself with respect to, and hence to 'engage' with, the other voices and alternative positions construed as being in play in the current communicative event'. (Martin and White 2005: 94). For this reason, the system offers a way into investigating how the teacher, as the 'authorial voice' during talk around picture books, adopts stances both in relation to the students and the visual-verbal components in texts, and in doing so, aligns or 'disaligns' the students with these positions. The unit of discourse taken up as the point of departure for analysis of spoken data is that of a 'message', which is proposed by Hasan (1995: 227) as 'capable of realizing an element in the structure of texts'.

The analysis in this section will now present examples of classroom talk collected for this study to demonstrate the various options within the Engagement system of the Appraisal theory. Brief explanations are provided following from each of the selected classroom talk in order to provide a linguistic description of individual semantic options within the Engagement system.

\section{Example 1}

Monoglossic

The English-speaking countries were having a very big war with Germany (message 1118)

\section{Heteroglossic}

...they thought that they might not be treated very well (message 1123)

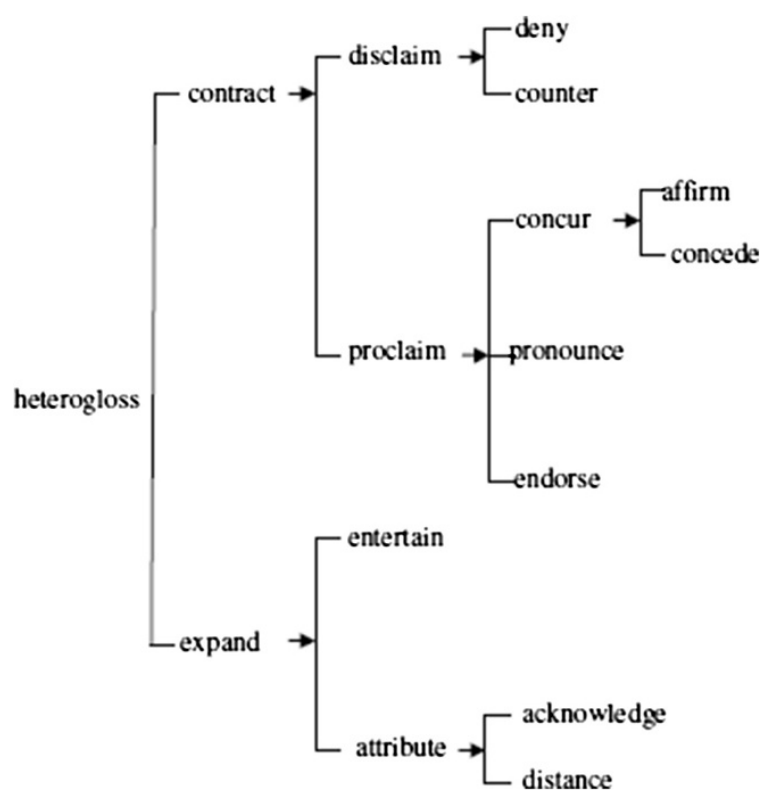

Figure 3 The Engagement system (Martin and White 2005). 
Any heteroglossic utterance can be treated as either contracting or expanding the dialogic space. If it contracts the space, the utterance 'acts to challenge, fend off or restrict' (Martin and White 2005: 102) other alternative positions and voices.

The two broad categories in which the function of 'contracting the space' can be achieved are to [disclaim] or to [proclaim]. The more delicate options of the former are [deny] and [counter], while the options [concur], [pronounce] and [endorse] belong to the latter option.

\section{Example 2}

[contract; disclaim; deny]

There are no mountains on the Moon (message 181)

Message 181 is an example of an utterance that functions to deny or reject the position that there are mountains on the Moon. Martin and White (2005: 118) propose that denials are commonly realised by negatives such as no, not or not the case. In the above example, the negative no acts to deny the presence of mountains on the Moon, and in doing so, rejects alternative positions other than the proposed formulation, which is the non-presence of mountains on the Moon.

\section{Example 3}

[contract; disclaim; counter]

Will everybody just find a seat please? (message 1416)

The adjunct just suggests that the imperative find a seat replaces any other actions that the students may be doing or wanting to do. In contrast to the two options previously discussed which directly reject or over-rule alternative positions, this option contracts the heteroglossic space by way of 'proclaiming' - that is, not to reject explicitly but rather to limit the scope of alternative positions.

\section{Example 4}

[contract; proclaim; concur]

Yes of course (message 804)

The formulation Yes of course announces the speaker's agreement with a previously proposed proposition. Following Martin and White (2005: 124), such formulations are contractive because they 'represent the shared value or belief' and in so doing, 'exclude any dialogistic alternatives', and at the same time 'position any who would advance such an alternative as at odds with what is purportedly generally agreed upon or known'.

\section{Example 5}

[contract; proclaim; pronounce] 
The category of [pronounce] describes explicit interventions or interpolations from the speaker through such formulations as I contend..., The facts of the matter are that..., You must agree that..., as well as the intensifiers really, indeed and so on (Martin and White 2005: 127). In other words, the speaker is seen to assert his/her authorial voice through such pronouncements which then fend off or challenge other viewpoints. Such pronouncements are often observed in the spoken data to be in the form of more explicit instructing by the teacher, $I$ want you, as in the example in message 418.

\section{Example 6}

[contract; proclaim; endorse]

What else that you can think of that shows it's a question? (message 266)

By endorsing, the speaker 'construes external sources as correct, valid [and] undeniable' (Martin and White 2005: 126). In message 266, the teacher's question asks the ways that show the statement in the text to be a question. The response to the question can be represented as ...show that it is a question. In short, she is not seeking to discuss the validity of the elements, i.e. the punctuation marks or Wh- tag, as indicators that the statement is a question. Rather, the verb show demonstrates that she construes these elements as undeniable and her purpose is to encourage the students to identify these elements.

The options that expand heteroglossic space, that is, open up the space for alternative positions and viewpoints are to [entertain] or to [attribute]. Propositions selecting the option [attribute] can be further categorised into the options [acknowledge] or [distance].

\section{Example 7}

[expand; entertain]

You might have another idea for the story (message 1605)

The distinction between the options [entertain] and [attribute] is that the former indicates 'its position as one of a number of possible positions' whereas the latter 'disassociates the proposition from the text's internal authorial voice by attributing it to some external source'

(Martin and White 2005: 104-111). Message 1605 demonstrates the value of entertain. The modal auxiliary might indicates the speaker's assessment of likelihood that the audience may have other possible ideas for the story, and thereby, recognises that its proposition is but one of a number of alternatives.

In comparison, the speaker in message 1343 is reporting on a proposition put forward by others as indicated in the verb say. Such formulations do not reveal the stance of the authorial voice.

\section{Example 8}

[expand; attribute; acknowledge] 
Nowhere in the spoken data does the teacher make use of the option [distance], that is, the explicit distancing of authorial voice from the attributed material.

\section{Methods}

Data for this study were obtained from a new arrivals classroom at a public primary school situated in the western suburbs of Adelaide, South Australia for the author's $\mathrm{PhD}$ study entitled 'Picture book reading in a new arrival context: A multimodal perspective on teaching reading'. The project had been approved by the University of Adelaide and the South Australian Department for Education and Child Development.

The main objective of the new arrivals curriculum is to provide English language support to newly-arrived students which then allows them to join a mainstream class in the same school or in other schools. The teacher observed in this study is a native English-speaker with thirty-five years teaching experience. Her educational qualifications include a Diploma of Teaching, Bachelor of Special Education, Master of Educational Psychology and Master by Research in Applied Linguistics. The student cohort consisted of nineteen students, ten female and nine male students. Of these nineteen students, sixteen were Year 7 and three were Year 6 students. The majority of the students were from Africa, mostly from the Sub-Saharan region, while the others were from Middle-Eastern and Asian backgrounds.

The interactions that took place during the reading of picture books were audiorecorded. Observations of lessons were undertaken five hours per week over a period of nine months in 2008. This paper draws on three one-hour lessons, with each focusing on a different picture book. These lessons were selected for analysis as they had an obvious emphasis on developing students' reading ability, as implicated in the large amount of reading and talking about picture books. In these sessions, the students were often divided into two groups. The first group of students comprised two subsets. The first were students who newly enrolled in the new arrivals program and had little or no literacy background due to a lack of prior schooling experiences. The second were those who, having been in the new arrivals program for a number of months, were still struggling with their reading and writing abilities. While this paper aims primarily at identifying the roles of teacher talk during picture book reading with new arrival students, it is necessary in some instances to comment on teacher talk with groups of differing literacy abilities as the teacher adopted different strategies with these students. For this reason, I shall label the group consisting of newly enrolled new arrivals as 'beginning students', and the second group consisting of those who had prior schooling and were able to read, write and interact with much less guidance is labelled as 'competent students'.

\section{Results}

This section presents the various roles of teacher talk around picture books that had surfaced from the analysis of Engagement meanings.

\section{In instructing 'beginning' and 'competent' students}

In Table 1 below, the teacher instructs the 'beginning students' to read the start of The Earth and the Moon: 
Table 1 Teacher talk that directs student focus

\begin{tabular}{lll}
\hline Interactant* & Message & Transcript \\
\hline $\mathrm{T}$ & 94 & Open the book \\
& 95 & and let's have a look at the beginning of the story \\
$\mathrm{S} 9$ & 96 & Can I read it? \\
$\mathrm{T}$ & 97 & Look we'll have to all take a chance \\
& 98 & Some of us will read together \\
& 99 & Alright S8 read \\
\hline
\end{tabular}

(*Please note that in the transcripts $\mathrm{T}=$ Teacher and $\mathrm{S}=$ Student.)

By directing students to the written words at the beginning of the text, the teacher fends off or restricts alternative positions other than that proposed by the teacher, such as the naming of objects from an image or discussing grammatical elements. The teacher voice encodes the engagement meaning of [proclaim] by acting to limit the students' scope of focus. Her instruction to S8 in message 99 further encodes the meaning [pronounce] whereby she explicitly intervenes to assert her proposition for the student to focus on the written text. By overtly directing the student focus to the written text, the teacher directs the reading path of the picture book which is to attend first to the written text on the page before its visual image.

This contrasts with the talk with the 'competent students' as the teacher brings their attention to Australia's Changing Voice, as in Table 2 below:

The teacher directs student attention to the picture book as they discuss the topic of Creole and Aboriginal languages. The mental verb I think, observed in the teacher talk, encodes the meaning [entertain], indicating her position as 'one of a number of possible positions and thereby, to greater or lesser degrees, makes dialogic space for those possibilities' (Martin and White 2005: 104). The rest of the exchange reveals that she does not point to any particular information on the page; rather, she encourages the students to explore the information on their own or with a partner. Teacher talk in this exchange entertains other dialogic alternatives by making room for student exploration of the information on the page as marked by her later talk I'm interested in what S3 has discovered... Tell them what you found out.

Table 2 Teacher talk that encourages student expressions

\begin{tabular}{lll}
\hline Interactant & Message & Transcript \\
\hline T & 1168 & In this book I think we have got a little bit of \\
1169 & If you look in this book \\
1170 & go to this page in the middle (holds book up) \\
1171 & One kind of Aboriginal language \\
1172 & have a look at that for the moment \\
1173 & Read with your partner \\
& 1174 & read some of those words \\
(Students read with their partners) & 1175 & Listen for just a moment \\
& 1176 & I'm interested in what S3 has discovered \\
& 1177 & Tell them what you found out \\
\hline
\end{tabular}


Differences in the way that the teacher engages the 'beginning students' and the 'competent students' in the reading of picture book texts are brought to light when the Engagement meanings in teacher talk are examined. When introducing the texts for book-reading, the distinction between the instructions to the 'beginning students' and the 'competent students' is clearest. Teacher talk targeting the 'beginning students' encodes the Engagement meaning of [proclaim], as she often brings their attention to specific sections of the text such as to a word/sentence, or to the object in an image. It is revealed that her instructions to the 'competent students' instead encodes the Engagement meaning [entertain], as she frequently encourages them to explore the text on their own or with a partner and to then share information that is relevant for class discussion. The 'competent students' are given more autonomy to explore the reading materials and to express their views in relation to the content, in comparison with the 'beginning students' who at most times are instructed to read the sentences in the texts.

\section{In lending support to writer voice}

Teacher talk during the reading lessons often emphasises the pattern of object-identification built into the text by the picture book writer, as for example in the extract in Table 3:

The teacher repeats the question posed through the writer voice Are there mountains on the Moon? (message 114), thereby eliciting a response from the students, and at the same time giving expression to reader voice as intended in the text. However, when the students do not provide the correct answer, which is that there are no mountains in the picture of the Moon, teacher voice counters the response by focusing student attention onto the visual image (message 116). She continues to challenge the students to locate the mountains in the picture as a way of countering the position of those students who responded Yes (messages 115 and 117). In the end, she explicitly tells the students the need to show the objects in the picture as a way of supporting their responses (message 119), and then proceeds to acknowledge the mountains in the image of the Earth.

Teacher voice here encodes the Engagement meaning [disclaim], or to be more specific [counter], in its role to support the intention of writer voice in the picture book. Instead of directly rejecting the student responses, teacher voice replaces it with a proposition to encourage reference to the image and to locate the object as implicated in the connective Then (message 118), followed by her countering proposition where are the mountains in that picture? The role of teacher voice here is significant as the

Table 3 Teacher talk that mediates between text and students

\begin{tabular}{lll}
\hline Interactant & Message & Transcript \\
\hline $\mathrm{T}$ & 114 & Are there mountains on the Moon? \\
$\mathrm{SS}$ & 115 & Yes \\
$\mathrm{T}$ & 116 & Can you see them in that picture? \\
$\mathrm{SS}$ & 117 & Yes... no...yes \\
$\mathrm{T}$ & 118 & Then where are the mountains in that picture? \\
& 119 & You need to show them \\
& 120 & There are mountains here \\
\hline
\end{tabular}


mediator between the text and the students, aligning them to the pattern of object identification intended by the writer.

Later in the classroom transcript, it is evident that the students have picked up the question-answer structure as demonstrated in the extract in Table 4:

The students no longer require the teacher's additional cue to respond to the question. As soon as the teacher repeats the question, all the students call out the correct response. The direction of talk then becomes less predictable as observed in the teacher's genuine comment My gosh I wonder who went up there, expressing her surprise at the information. Such a personal expression deviates from the sequence of talk dominating the earlier parts of the teacher-student interaction, where teacher talk frequently encodes the Engagement meanings of [disclaim] and [counter] that function primarily to guide the students to engage with the text in a specific way and at the same time 'contracting' the possibilities for the students to explore the text in other ways.

\section{In supplementing verbal text}

Apart from lending support to the writer voice, the teacher encourages student attention to the visual images in the picture book in order to supplement the interpretation of the story from the verbal text. A student's attempt to recount the story with little specificity in terms of differentiating between the characters is demonstrated in this example in Table 5:

The student's brief recount of the story does not differentiate the man as 'the swagman' or 'the squatter', which are the two male characters in the story. The teacher is seen to guide the students for the second time through the unfolding of the narrative, within which she focuses on identifying the characters and their individual roles in the story, as seen in Table 6:

In the message The man is called squatter (message 455), the teacher consciously differentiates between the characters in the story. She also details the different characters by focusing on their individual roles within the narrative, and at the same time deliberately referring to them through their names in the verbal text as squatter and swagman (messages 455 and 458). As well as making use of the verbal text, the teacher also engages the students with the visual images. She points students to the visual images in order to ensure that they are able to visually identify the characters as seen in her confirmatory questions (messages 471 and 475). On receiving an affirmation from the students, the teacher then aligns them to the terms used by narrator voice by referring them to instances in the verbal text (messages 477-486).

Table 4 Students gaining familiarity with question-answer structure

\begin{tabular}{lll}
\hline Interactant & Message & Transcript \\
\hline S7 & 229 & Are there footprints on the Moon? \\
$\mathrm{T}$ & 230 & Are there footprints on the Moon? \\
SS & 231 & Yes \\
$\mathrm{T}$ & 232 & Can you see any? \\
SS & 233 & Yes \\
$\mathrm{T}$ & 234 & Yes we can \\
& 235 & My gosh I wonder who went up there \\
\hline
\end{tabular}


Table 5 Student recount of narrative

\begin{tabular}{lll}
\hline Interactant & Message & Transcript \\
\hline S13 & 433 & The man going round the country \\
& 434 & the man...the man steal the sheep \\
435 & and the the the man see the man \\
& 436 & and the man jump in the water \\
\hline
\end{tabular}

It can be inferred that teacher voice, by bringing in and inviting student attention to the images, encodes the Engagement meaning of [attribute], or to be more specific [acknowledge]. The analysis demonstrates two findings; firstly that teacher talk takes on the significant role of scaffolding the students' interpretation of the individual characters at the point where the student talk suggested that they needed that guidance. More importantly, by focusing student attention on the characters in the visual image, the teacher is preparing the students to associate the visual depictions of these characters to their representation in the verbal text as demonstrated in her proposition Now in the song they're called another name... who is in here. The teacher makes use of the visual images as a way to support the propositions advanced in the verbal text, demonstrating her approach of the use of the verbal and visual modes in texts.

Table 6 Teacher talk that promotes association between text and images

\begin{tabular}{|c|c|c|}
\hline Interactant & Message & Transcript \\
\hline \multirow[t]{14}{*}{$\mathrm{T}$} & 447 & He wanted the sheep for his food \\
\hline & 448 & but the man who owns the sheep came along \\
\hline & 449 & and said no you can't take my sheep \\
\hline & 450 & I'm going to call the policemen \\
\hline & 451 & because you are stealing my sheep \\
\hline & 452 & and you're not allowed to steal my sheep \\
\hline & 453 & it's against the law \\
\hline & 454 & I won't let you steal my sheep \\
\hline & 455 & The man is called the squatter \\
\hline & 456 & He has lots of sheep \\
\hline & 457 & he owns lots of sheep \\
\hline & 458 & but he said no the swagman can't take my sheep \\
\hline & (Messages 460 - 470 omitted) & \\
\hline & 471 & So can you see the farmer? \\
\hline SS & 472 & Yeah \\
\hline $\mathrm{T}$ & 473 & Squatter \\
\hline SS & 474 & Yeah \\
\hline T & 475 & Can you see the policemen? \\
\hline SS & 476 & Yeah \\
\hline \multirow[t]{4}{*}{$\mathrm{T}$} & 477 & Now in the song they're called another name \\
\hline & 478 & who is in here \\
\hline & (Messages 479 - 483 omitted) & \\
\hline & 484 & [[Up came the troopers $]]$ \\
\hline SS & 485 & [[Up came the troopers] $]$ \\
\hline $\mathrm{T}$ & 486 & The policemen are called the troopers \\
\hline
\end{tabular}




\section{In identifying specific language or grammatical elements}

The type of interaction, of discussing language or grammatical elements, as presented in Table 7 is most frequently observed in this study:

Teacher voice interposes in the interaction (message 259) to bring the students' attention to the recognition of the statement-question structure, which is utilised by the writer voice to draw on the reader's participation in the intended activity. The interaction centres on the identification of punctuation, i.e. question mark.

The teacher's position in relation to the value of the picture book materials is clear as the Engagement meanings are examined in her talk. When highlighting the language structures or items in the picture books (messages 263-266), she construes these resources as correct, valid and undeniable, thereby fulfilling the Engagement meaning of [endorse]. In other words, the use of the language items in the texts is not set up by the teacher to be challenged or debated upon in the discussion. Rather, the particular language items serve as correct or ideal instances of usage as indicated in the teacher's evaluation of the verbal text So that's a good way to begin a question... (message 265). In other words, she uses the picture book texts to demonstrate appropriate usage of grammatical elements and guides the students towards recognising the language patterns.

\section{Discussion}

The analysis has revealed features in one teacher's talk as she engages new arrival students in reading and talking about picture books. The analysis of teacher talk drew on Martin and White's (2005) Appraisal theory, specifically the Engagement system,

Table 7 Teacher talk that brings student awareness to language and grammatical elements

\begin{tabular}{|c|c|c|}
\hline Interactant & Message & Transcript \\
\hline \multirow[t]{2}{*}{$\overline{\mathrm{T}}$} & 256 & What did the question ask about the Moon? \\
\hline & 257 & Are there... \\
\hline SS & 258 & Are there mountains on the Moon? \\
\hline $\mathrm{T}$ & 259 & How do we know that's a question S4? \\
\hline \multirow[t]{4}{*}{$\mathrm{T}$} & 263 & The way the words are written gives us a clue \\
\hline & 264 & It says Are there \\
\hline & 265 & So that's a good way to begin a question are there or is there \\
\hline & 266 & What else that you can think of that shows it's a question? \\
\hline $\mathrm{S}$ & 267 & Moon \\
\hline $\mathrm{T}$ & 268 & Something about the punctuation \\
\hline $\mathrm{S} 10$ & 269 & Question... \\
\hline $\mathrm{T}$ & 270 & The question... ((mark)) \\
\hline SS & 271 & $(($ mark $))$ \\
\hline \multirow[t]{3}{*}{$\mathrm{T}$} & 272 & When we ask a question and we're writing it down, \\
\hline & 273 & we use that special question mark that goes at the... \\
\hline & 274 & Where does it go? \\
\hline S & 275 & The end of the... \\
\hline \multirow[t]{3}{*}{$\mathrm{T}$} & 276 & The end of the question \\
\hline & 277 & Some of the words will help us know it's a question \\
\hline & 278 & because of how they begin Are there \\
\hline
\end{tabular}


which has proven to be useful for uncovering a number of characteristics of teacher talk around picture books related to: i) the ways that the teacher valued the text and specific modes within the text, including whether she approved or disapproved the text as well as whether prominence was given to either the verbal or visual system; and ii) the ways that the teacher adopted stance as well as negotiated rapport with the students towards engagement with the resources in the texts and importantly, how she aligned or disaligned them to do likewise.

Findings from the analysis suggested that the teacher did prioritise the verbal mode over the visuals when using picture books with the students. It was found that the teacher often directed attention to the images for the purpose of preparing the students for further instructions on the verbal text. The options within the Engagement system demonstrated how the students, whose contributions aligned in this way, were acknowledged by the teacher or otherwise countered and re-aligned to her intended focus. Therefore, it can be said that the teacher placed more emphasis on learning from and about the verbal text, with attention to the visuals functioning to support learning from the verbal mode.

Developing teacher understanding about the semiotic system of visual images has potentially important implications for pedagogic practices around teaching reading (Stenglin and Iedema 2001). Informed understandings about the meaning affordances of the visual images and of how the visual mode, like the verbal mode, comprises a systematic grammatical set of meanings can translate to an increased awareness of the roles and functions of images in picture books (Kress and van Leeuwen 1996). The analysis has shown that the teacher focused and emphasised student attention on the verbal text. Her practices came from her knowledge about the role of the verbal text in the construction of meanings in the texts. The same could not be achieved in relation to the engagement with the visual mode due to the lesser degree of understanding around the semiotic system of visual images. Professional development in this area potentially benefits teachers in a number of ways; in choosing texts for reading with students, in planning and programming curriculum based on increased understanding and knowledge about picture books, and in their scaffolding exchanges with students during reading lessons.

Analysis of teacher talk also revealed her attitude towards the picture books. Drawing upon the Engagement system, it was found that teacher talk displayed characteristics that revealed her attitude to be one where she valued the material and recognised the information within them as valid, undeniable or unchallengeable. Her talk around the picture books indicated that she treated the texts as exemplary texts, drawing from within them examples of language use for the purpose of demonstrating to the students appropriate usage of grammatical or language items.

Another outcome of the analysis was in realising differences in the way that the teacher instructed the 'beginning' and the 'competent' students. Teacher talk with the 'competent' students frequently encoded characteristics that created opportunities for the students to engage in discourse in a less-restrictive way. For example, the teacher was often found to adopt indefinite positions on a topic related to the narrative and instead encouraged the students to express their personal opinions. In contrast, talk between the teacher and the 'beginning' students was more restrictive. The analysis revealed that teacher talk was limited to eliciting short or yes/no responses such as those 
that focused student attention onto specific parts of the texts. This kind of talk limits opportunities for students to express and to explore parts of a text that may have been of interest to them.

\section{Conclusion}

This paper has attempted to use the Engagement system of the Appraisal theory to examine teacher talk. The primary advantage that has surfaced from the use of the Appraisal theory for this analysis is in its capacity to trace teacher talk for its expressions of feelings or attitudes, thereby revealing the teacher's intentions at particular points of her talk with the students. The analytical tool, afforded by the Engagement system, has been useful for the analysis of teacher talk in this study as it had allowed for a linguistic description of the teacher's approach to inducting new arrival students to ways of engaging with reading and talking about picture book texts. Discussion of the analysis uncovers the teacher's stance and the alignment or disalignment of students to the stance identified in the picture book texts, as well as the teacher's self-positioning in relation to the students', the writer's and the illustrator's voices that were all a part of the classroom interaction around children's picture books. More studies are needed, especially in different contexts, in order to generalise the use of the Engagement system on teacher talk.

\section{Competing interests}

The author declares that she has no competing interests.

Received: 22 July 2014 Accepted: 31 October 2014

Published online: 02 December 2014

\section{References}

Christie, F. 2002. Classroom Discourse Analysis: A Functional Perspective. London: Continuum.

DEECD (Department of Education and Early Childhood Development). 2008. Strengthening Outcomes: Refugee Students in Government Schools. Melbourne: The ESL Unit, Student Learning Programs Division, Office for Government School Education.

Goodman, KS. 1967. Reading: a psycholinguistic guessing game. Journal of the Reading Specialist 5: 674-691.

Gough, PB. 1972. One Second of Reading. In Language by Ear and by Eye: The Relationship between Speech and Reading, ed. F Kavanaugh and IG Mattingly, 331-358. Cambridge, MA: The MIT Press.

Halliday, MAK. 1978. Language as Social Semiotic: The Social Interpretation of Language and Meaning. Maryland: University Park Press.

Halliday, MAK, and CMIM Matthiessen. 2004. An Introduction to Functional Grammar, 3rd ed. London: Arnold.

Hasan, R. 1991. Questions as a Mode of Learning in Everyday Talk. In Language Education: Interaction and Development, ed. T Le and M McCausland, 70-119. Launceston: University of Tasmania.

Hasan, R. 1995. The Conception of Context in Text. In Discouse in Society, ed. P Fries and M Gregory, 183-283. NJ: Ablex.

Hood, S. 2010. Appraising Research: Evaluation in Academic Writing. London: Palgrave Macmillan.

Hood, S, and JR Martin. 2007. Invoking Attitude: The Play of Graduation in Appraising Discourse. In Continuing Discourse on Language: A Functional Perspective Volume 2, ed. R Hasan, C Matthiessen, and J Webster, 739-764. London: Equinox.

Kress, G, and T van Leeuwen. 1996. Reading Images: The Grammar of Visual Design, 1st ed. New York: Routledge.

Martin, JR. 2000a. Factoring out Exchange: Types of Structure. In Working with Dialogue, ed. M Coulthard, J Cotterill, and F Rock, 19-40. Tubingen: Niemeyer.

Martin, JR. 2000b. Beyond exchange: Appraisal systems in English. In Evaluation in Texts: Authorial Stance and The Construction of Discourse, ed. S Hunston and G Thompson, 142-175. Oxford: Oxford University Press.

Martin, JR. 2001. Mourning: how we get aligned. Discourse \& Society 15(2-3): 321-344.

Martin, JR. 2014. Evolving systemic functional linguistics: beyond the clause. Functional Linguistics 1(3): 1-24.

Martin, JR, and D Rose. 2003. Working with Discourse: Meaning Beyond The Clause, 1st ed. London: Continuum. Martin, JR, and D Rose. 2005. Designing Literacy Pedagogy: Scaffolding Democracy in the Classroom. In Continuing Discourse on Language: A Functional Perspective, Volume 1, ed. R Hasan, CMIM Matthiessen, and J Webster, 251-280. London and Oakville: Equinox.

Martin, JR, and D Rose. 2008. Genre Relations: Mapping Culture. London: Equinox.

Martin, JR, and PRR White. 2005. The Language of Evaluation: Appraisal in English. London: Palgrave.

O'Halloran, K. 1999. Towards a systemic functional analysis of multisemiotic mathematics texts. Semiotica 124(1/2): 1-29.

Rose, D. 2004. Sequencing and Pacing of the Hidden Curriculum: How Indigenous Children are Left out of the Chain. In Reading Bernstein, Researching Bernstein, ed. J Muller, A Morais, and B Davies, 91-107. London: Routledge Falmer. 
Rose, D. 2007. A Reading Based Model of Schooling. Pesquisas em Discurso Pedagogico 4(2). http://www.maxwell.vrac. pucrio.br/rev_discurso.php?strSecao=input0. Accessed on 23 October 2010.

Smith, F. 1971. Understanding Reading: A Psycholinguistic Analysis of Reading and Learning to Read. New York: Holt, Rinehart \& Winston.

Smith, F. 1983. Reading like a writer. Language Arts 60(5): 558-567.

Smith, F. 1994. Understanding Reading: A Psycholinguistic Analysis of Reading and Learning to Read, 5th ed. Hillsdale, $\mathrm{NJ}$ : Lawrence Erlbaum Associates.

Stenglin, M, and R ledema. 2001. How to Analyse Visual Images: A Guide for TESOL Teachers. In Analysing English in a Global Context: A Reader, ed. A Burns and C Coffin, 194-208. London: Routledge in association with Macquarie University and the Open University.

Thomson, E, P White, and P Kitley. 2010. "Objectivity" and "Hard News" Reporting Across Cultures: Comparing the News Report in English, French, Japanese and Indonesian Journalism. In Language and Journalism, ed. JE Richardson, 61-77. London and New York: Routledge, Taylor and Francis Group.

Thorne, K, and N Gericke. 2014. Teaching genetics in secondary classrooms: a linguistic analysis of Teachers' talk about proteins. Research in Science Education 44(1): 81-108.

Thwaite, A. 2014. Teachers and teacher aides initiating five-year olds into science. Functional Linguistics 1(6): 1-15.

Thwaite, A, and G McKay. 2013. Five year olds doing science and technology: How teachers shape the conversation. Australian Journal of Language and Literacy 36(1): 28-37.

Unsworth, L, and C Cleirigh. 2009. Multimodality and Reading: The Construction of Meaning Through Image-Text Interaction. In The Routledge Handbook of Multimodal Analysis, ed. C Jewitt, 151-163. London: Routledge.

White, P. 2006. Evaluative Semantics and Ideological Positioning in Journalistic Discourse: A new Framework for Analysis. In Mediating Ideology in Text and Image: Ten Critical Studies (Discourse Approaches to Politics, Society and Culture), ed. I Lassen, J Strunck, and T Vestergaard, 37-67. Amsterdam: John Benjamins.

doi:10.1186/s40554-014-0012-3

Cite this article as: Chu: Supporting new arrival students' engagement with picture books: analysis of teacher talk using the appraisal theory. Functional Linguistics 2014 1:12.

\section{Submit your manuscript to a SpringerOpen ${ }^{\circ}$ journal and benefit from:}

- Convenient online submission

- Rigorous peer review

- Immediate publication on acceptance

- Open access: articles freely available online

- High visibility within the field

- Retaining the copyright to your article

Submit your next manuscript at $\boldsymbol{\text { springeropen.com }}$ 